\title{
Effects of L-Leucine on the Insulin Production, Oxidative Metabolism and Mitochondrial Ultrastructure of Isolated Mouse Pancreatic Islets in Tissue Culture*
}

\author{
A. Andersson, J. Höiriis-Nielsen and L. A. H. Borg \\ Department of Histology, University of Uppsala, Sweden, and Steno Memorial Hospital, Gentofte, Denmark
}

\begin{abstract}
Summary. This study was performed to evaluate whether L-leucine is able to relieve the structural and functional alterations previously described in pancreatic islets exposed in vitro for a prolonged time to a subnormal glucose concentration $(3.3 \mathrm{mM})$. It was found that both the impairment of secretion and the decreased rate of biosynthesis of insulin characteristic of islets cultured for one week in $3.3 \mathrm{mM}$ glucose were prevented by adding $15 \mathrm{mM}$ L-leucine to the culture medium. Furthermore, the rates of tritiated water production and glucose or leucine oxidation were significantly enhanced after culture in the presence of L-leucine. The rate of DNA synthesis as estimated by the incorporation of tritiated thymidine was, however, unchanged by the presence of L-leucine in the culture medium. Leucine cultured islet cells displayed ultrastructural signs of high functional activity. A detailed morphometric examination revealed fewer but hypertrophic mitochondria. The present results suggest that L-leucine can replace glucose in several respects as a long-term stimulus of the pancreatic B-cells, possibly by acting as a metabolic substrate.
\end{abstract}

Key words: Pancreatic islets, tissue culture, ultrastructure, morphometry, mitochondria, L-leucine, B-cell function. stood. It has been suggested that insulin release is triggered by the binding of the amino acid to specific transport sites in the plasma membrane [13] or, alternatively, that amino acids stimulate insulin release through metabolic processes within the pancreatic $\mathrm{B}$-cells comparable to those induced by glucose [32]. In order to further elucidate the mechanisms behind the stimulatory action of L-leucine on the islets of Langerhans we used a tissue culture system [6] in which isolated pancreatic islets were maintained in culture for one week with a substimulatory extracellular glucose concentration $(3.3 \mathrm{mM})$ and in the presence of $15 \mathrm{mM} \mathrm{L}$-leucine. Previous studies have shown that culture of pancreatic islets in a medium containing $3.3 \mathrm{mM}$ glucose and a low leucine concentration $(<0.5 \mathrm{mM})$ leads to an impaired insulin secretion in response to a sudden glucose load, a decrease in insulin biosynthesis and marked changes of the oxidative metabolism of the islet cells and of their mitochondrial ultrastructure $[5,7,11]$. It was the primary aim of the present study to determine whether L-leucine might replace glucose as the metabolic substrate and insulin secretagogue of pancreatic B-cells maintained in tissue culture.

\section{Materials and Methods}

It has been known for many years that certain amino acids increase the serum insulin concentration [17] and experiments performed in vitro have shown that this is due to a direct stimulation of the pancreatic B-cells [33]. The mode of action by which amino acids elicit insulin release is, however, still poorly under-

\footnotetext{
* Presented in part at the Congresses of the European Association for the Study of Diabetes, Munich, 1975 and Helsinki, 1976
}

\section{Tissue Culture}

Adult male NMRI-mice were starved overnight before the experiments. Isolated islets were obtained under aseptic conditions by a modified collagenase method [27] and further treated for tissue culture as recently described [6]. The culture medium consisted of $5 \mathrm{ml}$ TCM 199 (Statens Bakteriologiska Laboratorium, Stockholm, Sweden) supplemented with $10 \%(\mathrm{v} / \mathrm{v})$ calf serum, $100 \mathrm{units} / \mathrm{ml}$ penicillin and 
Table 1. Effects of $15 \mathrm{mM}$ L-leucine on the morphometric parameters of cultured islet cells and islet cell mitochondria

\begin{tabular}{|c|c|c|c|c|c|c|}
\hline \multicolumn{2}{|c|}{ Morphometric parameter } & \multicolumn{2}{|c|}{ Islets cultured in $15 \mathrm{mM} \mathrm{L}$-leucine } & \multicolumn{2}{|c|}{ Islets cultured in $0.5 \mathrm{mM}$ L-leucine } & \multirow{2}{*}{$\begin{array}{l}\text { Statistical } \\
\text { significance }\end{array}$} \\
\hline & Dimension & Mean \pm SEM & $\mathbf{n}$ & Mean \pm SEM & $\mathrm{n}$ & \\
\hline $\mathrm{V}_{\mathrm{vC}}$ & $\mathrm{mm}^{3} / \mathrm{mm}^{3}$ & $1.000^{\mathrm{a}}$ & & $1.000^{\mathrm{a}}$ & & \\
\hline $\mathrm{S}_{\mathrm{vc}}$ & $\mathrm{mm}^{2} / \mathrm{mm}^{3}$ & $533 \pm 19$ & 28 & $550 \pm 21$ & 28 & n.s. \\
\hline $\mathrm{N}_{\mathrm{VC}}$ & $1 / \mathrm{mm}^{3}$ & $1.26 \cdot 10^{6} \pm 0.09 \cdot 10^{6}$ & 28 & $1.32 \cdot 10^{6} \pm 0.07 \cdot 10^{6}$ & 28 & n.s. \\
\hline $\mathrm{V}_{\mathrm{vC}} / \mathrm{N}_{\mathrm{vc}}$ & $\mathrm{mm}^{3}$ & $0.79 \cdot 10^{-6} \pm 0.05 \cdot 10^{-6}$ & 28 & $0.75 \cdot 10^{-6} \pm 0.04 \cdot 10^{-6}$ & 28 & n.s. \\
\hline $\mathrm{S}_{\mathrm{vC}} / \mathrm{N}_{\mathrm{vC}}$ & $\mathrm{mm}^{2}$ & $0.43 \cdot 10^{-3} \pm 0.03 \cdot 10^{-3}$ & 28 & $0.42 \cdot 10^{-3} \pm 0.03 \cdot 10^{-3}$ & 28 & n.s. \\
\hline $\mathrm{V}_{\mathrm{VM}}$ & $\mathrm{mm}^{3} / \mathrm{mm}^{3}$ & $0.050 \pm 0.002$ & 168 & $0.060 \pm 0.003$ & 168 & $\mathrm{p}<0.01$ \\
\hline $\mathrm{S}_{\mathrm{VM}}^{\mathrm{VM}}$ & $\mathrm{mm}^{2} / \mathrm{mm}^{3}$ & $451 \pm 19$ & 168 & $616 \pm 31$ & 168 & $\mathrm{p}<0.001$ \\
\hline$S_{\mathrm{VMC}}$ & $\mathrm{mm}^{2} / \mathrm{mm}^{3}$ & $4070 \pm 271$ & 336 & $4410 \pm 263$ & 336 & n.s. \\
\hline $\mathrm{N}_{\mathrm{VM}}$ & $1 / \mathrm{mm}^{3}$ & $274 \cdot 10^{6} \pm 15 \cdot 10^{6}$ & 168 & $446 \cdot 10^{6} \pm 30 \cdot 10^{6}$ & 168 & $\mathrm{p}<0.001$ \\
\hline $\mathrm{V}_{\mathrm{VM}} / \mathrm{N}_{\mathrm{VM}}$ & $\mathrm{mm}^{3}$ & $185 \cdot 10^{-12} \pm 13 \cdot 10^{-12}$ & 168 & $129 \cdot 10^{-12} \pm 11 \cdot 10^{-12}$ & 168 & $p<0.001$ \\
\hline $\mathrm{S}_{\mathrm{VM}} / \mathrm{N}_{\mathrm{VM}}$ & $\mathrm{mm}^{2}$ & $1.65 \cdot 10^{-6} \pm 0.11 \cdot 10^{-6}$ & 168 & $1.32 \cdot 10^{-6} \pm 0.11 \cdot 10^{-6}$ & 168 & $\mathrm{p}<0.05$ \\
\hline $\mathrm{S}_{\mathrm{VM}} / \mathrm{V}_{\mathrm{VM}}$ & $\mathrm{mm}^{2} / \mathrm{mm}^{3}$ & $8.90 \cdot 10^{3} \pm 0.53 \cdot 10^{3}$ & 168 & $10.25 \cdot 10^{3} \pm 0.74 \cdot 10^{3}$ & 168 & n.s. \\
\hline $\mathrm{S}_{\mathrm{VMC}} / \mathrm{N}_{\mathrm{VM}}$ & $\mathrm{mm}^{2}$ & $14.87 \cdot 10^{-6} \pm 1.62 \cdot 10^{-6}$ & 168 & $9.47 \cdot 10^{-6} \pm 1.00 \cdot 10^{-6}$ & 168 & $\mathrm{p}<0.001$ \\
\hline $\mathrm{S}_{\mathrm{VMC}} / \mathrm{V}_{\mathrm{VM}}$ & $\mathrm{mm}^{2} / \mathrm{mm}^{3}$ & $80.2 \cdot 10^{3} \pm 8.3 \cdot 10^{3}$ & 168 & $73.4 \cdot 10^{3} \pm 7.3 \cdot 10^{3}$ & 168 & n.s. \\
\hline $\mathrm{V}_{\mathrm{VM}} / \mathrm{N}_{\mathrm{VC}}$ & $\mathrm{mm}^{3}$ & $40.1 \cdot 10^{-9} \pm 4.9 \cdot 10^{-9}$ & 28 & $45.3 \cdot 10^{-9} \pm 6.2 \cdot 10^{-9}$ & 28 & n.s. \\
\hline $\mathrm{S}_{\mathrm{VM}} / \mathrm{N}_{\mathrm{VC}}$ & $\mathrm{mm}^{2}$ & $0.36 \cdot 10^{-3} \pm 0.04 \cdot 10^{-3}$ & 28 & $0.46 \cdot 10^{-3} \pm 0.06 \cdot 10^{-3}$ & 28 & n.s. \\
\hline $\mathrm{S}_{\mathrm{VM}} / \mathrm{S}_{\mathrm{VC}}$ & $\mathrm{mm}^{2} / \mathrm{mm}^{2}$ & $0.85 \pm 0.09$ & 28 & $1.12 \pm 0.14$ & 28 & n.s. \\
\hline $\mathrm{S}_{\mathrm{VMC}} / \mathrm{N}_{\mathrm{VC}}$ & $\mathrm{mm}^{2}$ & $3.22 \cdot 10^{-3} \pm 0.77 \cdot 10^{-3}$ & 28 & $3.33 \cdot 10^{-3} \pm 0.71 \cdot 10^{-3}$ & 28 & n.s. \\
\hline $\mathrm{S}_{\mathrm{VMC}} / \mathrm{S}_{\mathrm{VC}}$ & $\mathrm{mm}^{2} / \mathrm{mm}^{2}$ & $7.64 \pm 1.78$ & 28 & $8.01 \pm 1.68$ & 28 & n.s. \\
\hline $\mathrm{N}_{\mathrm{VM}} / \mathrm{N}_{\mathrm{VC}}$ & & $220 \pm 30$ & 28 & $350 \pm 60$ & 28 & $\mathrm{p}<0.05$ \\
\hline $\mathrm{N}_{\mathrm{VM}} / \mathrm{S}_{\mathrm{VC}}$ & $1 / \mathrm{mm}^{2}$ & $0.51 \cdot 10^{6} \pm 0.07 \cdot 10^{6}$ & 28 & $0.85 \cdot 10^{6} \pm 0.14 \cdot 10^{6}$ & 28 & $\mathrm{p}<0.05$ \\
\hline
\end{tabular}

The primary morphometric parameters are:

$\mathrm{V}_{\mathrm{vc}}=$ Volume of islet cells per unit test volume

$\mathrm{S}_{\mathrm{VC}} \quad=$ Surface area of islet cells per unit test volume

$\mathrm{N}_{\mathrm{vC}}=$ Number of islet cells per unit test volume

$\mathrm{V}_{\mathrm{VM}}=$ Volume of mitochondria per unit test volume

$\mathrm{S}_{\mathrm{VM}}=$ Surface area of mitochondria per unit test volume

$S_{\mathrm{VMC}}=$ Surface area of mitochondrial cristae per unit test volume

$\mathrm{N}_{\mathrm{VM}}=$ Number of mitochondria per unit test volume

The secondary morphometric parameters are quotients of the primary parameters.

$\mathrm{n} \quad=$ The number of electron micrographs analyzed

a $\mathrm{V}_{\mathrm{VC}}$ is assigned the value of 1.000 as explained in the text

$0.1 \mathrm{mg} / \mathrm{ml}$ streptomycin. The glucose concentration of the culture medium was adjusted to $3.3 \mathrm{mM} .15 \mathrm{mM}$ L-leucine was added to the test medium, while the control medium contained less than $0.5 \mathrm{mM}$ L-leucine. Both media had an osmolality of $325 \pm 25$ mOsmol as estimated by measurements of the freezing-point depression. The medium was changed on the third and fifth days of culture. On the seventh day of culture the islets were harvested mechanically from the bottom of the dishes by careful scraping with a thin piece of rubber ("rubber policeman").

\section{Electron Microscopy}

The harvested islets were washed twice in Hanks' solution and then fixed for electron microscopy by immersion in a medium consisting of $2.5 \%(\mathrm{v} / \mathrm{v})$ glutaraldehyde in $0.05 \mathrm{M}$ phosphate-buffer adjusted to $\mathrm{pH} 7.2$ and with an osmolality of $390 \mathrm{mOsmol}$. The specimens were postfixed in $1 \%(\mathrm{w} / \mathrm{v})$ osmium tetrox- ide in the same buffer and subsequently dehydrated and embedded in an epoxy resin (Epon 812 ${ }^{\circledR}$ ) [31]. Ultrathin sections giving a silvery interference colour were picked up on Formvar coated one hole grids and subsequently stained with uranyl acetate [36] and lead citrate [34]. Electron microscopy was carried out with a TEM Jeol $100 \mathrm{~B}$ at $60 \mathrm{kV}$ acceleration voltage.

\section{Morphometric Analysis}

The ultrastructural morphometry was mainly carried out as recently described by Borg et al. [11]. For abbrevations of the morphometric parameters see Table 1.

Seven islets from each experimental group were prepared for electron microscopy and one ultrathin section from each of these islets was chosen at random and analysed stereologically. Three sets of electron micrographs were made from each of the two experimental groups: one consisting of 28 micrographs at a 
primary magnification of $1670 \times$ for the estimation of $\mathrm{S}_{\mathrm{VC}}$ and $\mathrm{N}_{\mathrm{VC}}$; another consisting of 168 micrographs at $5300 \times$ for the estimation of $\mathrm{V}_{\mathrm{VM}}, \mathrm{S}_{\mathrm{VM}}$ and $\mathrm{N}_{\mathrm{VM}}$; and one of 336 micrographs at $19200 \times$ for the estimation of $\mathrm{S}_{\mathrm{VMC}}$.

$V_{V M}$ was measured as described by Glagoleff [19], while $S_{\mathrm{VC}}, S_{\mathrm{VM}}$ and $S_{\mathrm{VMC}}$ were estimated according to Tomkeieff [35] and Hennig [24].

Calculations of $\mathrm{N}_{\mathrm{VC}}$ were based on the equation of De Hoff and Rhines [15]:

$\mathrm{N}_{\mathrm{V}}=\frac{\mathrm{N}_{\mathrm{A}}}{\overline{\mathrm{D}}}$

In this equation $\mathrm{N}_{\mathrm{V}}$ is the total number of features per unit test volume and $\mathrm{N}_{\mathrm{A}}$ the number of intercepts of features per unit test area. $\bar{D}$ is defined as the average tangent diameter and depends on the size distribution and shape of the corpuscle under consideration. Furthermore an exact relationship exists between $\overline{\mathrm{D}}$ and $V_{V} / S_{V}$ for various corpuscles of well defined shape. This relationship can be calculated from formulae given by Hilliard [25]. As deduced from our electron micrographs the islet cells are angulated spheroid bodies and since $\overline{\mathrm{D}}=6.91556 \cdot \mathrm{V}_{\mathrm{V}} / \mathrm{S}_{\mathrm{V}}$ for an icosahedron and $\overline{\mathrm{D}}=7.12104 \cdot \mathrm{V}_{\mathrm{V}} / \mathrm{S}_{\mathrm{V}}$ for a pentagonal dodecahedron a valid approximation for these particular cells is:

$\overline{\mathrm{D}}_{\mathrm{C}}=7 \cdot \mathrm{V}_{\mathrm{VC}} / \mathrm{S}_{\mathrm{VC}}$

and Eq. 1 thus becomes:

$\mathrm{N}_{\mathrm{VC}}=\frac{\mathrm{N}_{\mathrm{AC}} \cdot \mathrm{S}_{\mathrm{VC}}}{7 \cdot \mathrm{V}_{\mathrm{VC}}}$

The volume fraction $\left(\mathrm{V}_{\mathrm{vc}}\right)$ of islet cells in cultured islet tissue is considered to be unity, since vascular structures disappear early during culture.

$\mathrm{N}_{\mathrm{VM}}$ was calculated in accordance with the equation of Weibel [37]. The shape coefficient for mitochondria was estimated to 1.6 for both experimental groups and the coefficient of size distribution was given an arbitrary value $(K=1.05)$ according to principles described elsewhere [11].

All calculations and the statistical analysis of mean values, standard errors of the means (SEM) and Student's t-tests were carried out with a programmable calculator (Compucorp 445 Statistician ${ }^{\circledR}$ ).

\section{Insulin Release}

Accumulation of insulin in the culture medium was followed by determinations of the insulin content of a $100 \mu \mathrm{l}$ sample taken at each medium change. For studies of the insulin secretion in short-term experi- ments at the end of the culture period the islets were incubated in groups of 10 for 60 or $120 \mathrm{~min}$ at $+37^{\circ} \mathrm{C}$ in a bicarbonate-buffered medium [28] supplemented with $2 \mathrm{mg} / \mathrm{ml}$ albumin and $10 \mathrm{mM}$ HEPES in a gas phase consisting of $5 \% \mathrm{CO}_{2}$ and $95 \% \mathrm{O}_{2}$. Glucose, L-leucine and theophylline were added as described below. The insulin content of groups of 10 islets was measured by extraction in acid ethanol $(1.5 \mathrm{ml}$ of $12 \mathrm{M}$ $\mathrm{HCl}$ in $100 \mathrm{ml} 75 \%(\mathrm{v} / \mathrm{v})$ ethanol) over-night at $+4^{\circ}$ C. Radioimmunological assays of insulin in incubation media and islet extracts were made according to Heding [21] using crystalline mouse insulin as a standard.

\section{Tritiated Water Production}

Islets in groups of 10 were incubated for $120 \mathrm{~min}$ in a bicarbonate-buffered medium [28]. The formation of ${ }^{3} \mathrm{H}_{2} \mathrm{O}$ from $5-\left[{ }^{3} \mathrm{H}\right]$-glucose was estimated essentially as described by Ashcroft et al. [8].

\section{Oxidation of Glucose and Leucine}

Groups of ten cultured islets were incubated in a bicarbonate-buffered medium [18] containing either $\mathrm{D}-\left[\mathrm{U}-{ }^{14} \mathrm{C}\right]$-glucose or $\mathrm{L}-\left[\mathrm{U}-{ }^{14} \mathrm{C}\right]$-leucine. Details of the incubation technique and calculations of the results from the production of ${ }^{14} \mathrm{CO}_{2}$ have recently been described [1].

\section{Insulin Biosynthesis}

The cultured islets were incubated in groups of 25 for $120 \mathrm{~min}$ in a bicarbonate-buffered medium [18] supplemented with $100 \mu \mathrm{Ci} / \mathrm{ml} \mathrm{L}-\left[4,5-{ }^{3} \mathrm{H}\right]$-leucine $(58$ $\mathrm{Ci} / \mathrm{mM})$ or $200 \mu \mathrm{Ci} / \mathrm{ml}$ L-phenyl- $\left[2,3-{ }^{3} \mathrm{H}\right]$-alanine $(20 \mathrm{Ci} / \mathrm{mM}$ - The Radiochemical Centre, Amersham, England), 3.3 or $16.7 \mathrm{mM}$ glucose and amino acids as according to Eagle [16], except that either leucine or phenylalanine was omitted. The protein biosynthesis was estimated as the incorporation of labelled leucine or phenylalanine into both insulin immunoreactive material and into TCA-precipitable proteins. Labelled proinsulin and insulin were separated from other islet proteins by means of an immune binding technique, recently described in detail by Berne [9].

\section{DNA Synthesis}

On the fourth day of culture the medium was changed and ${ }^{3} \mathrm{H}$-thymidine $(5.0 \mathrm{Ci} / \mathrm{mM}$ - The Radiochemical Centre, Amersham, England) was added to a final concentration of $1 \mu \mathrm{Ci} / \mathrm{ml}$. For further details of the experimental procedure reference should be made to Andersson [2]. 


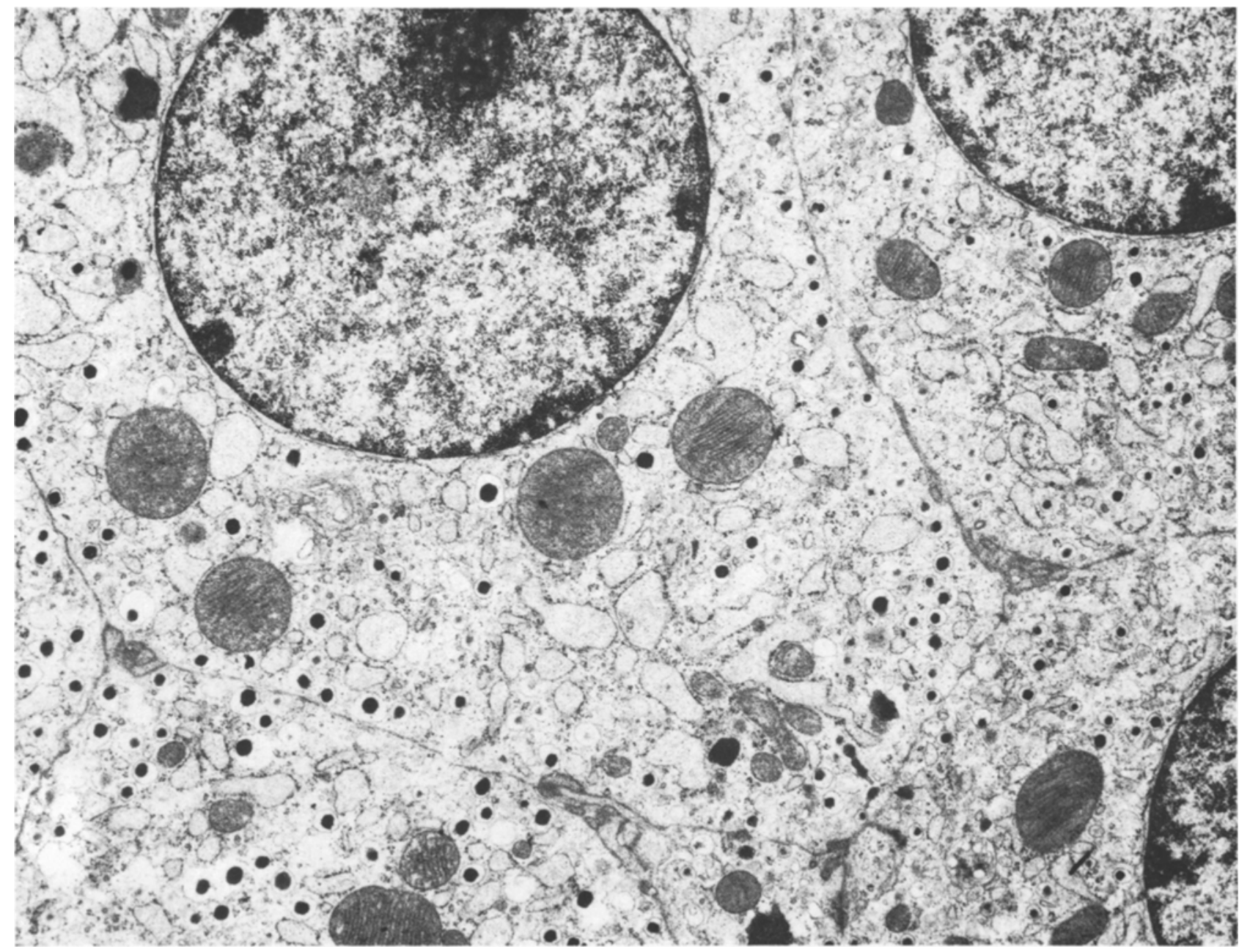

Fig. 1. Electron micrograph showing B-cells of a pancreatic islet cultured for one week in $15 \mathrm{mM} \mathrm{L-leucine.} \times 12300$

\section{Results}

\section{Ultrastructure}

The B-cells of the islets cultured in the presence of 15 mM L-leucine (Fig. 1) had seemingly well developed nucleoli and the granulated endoplasmic reticulum was most frequently vacuolar but sometimes also lamellar. Furthermore the Golgi apparatus consisted of prominent cisternae, vacuoles and vesicles. The number of secretory granules was below that found in normally granulated B-cells and only a few lysosomes were seen. In contrast to these findings the B-cells of the control islets (Fig. 2) had less prominent nucleoli and sparse elements of the endoplasmic reticulum and the Golgi apparatus. Both secretory granules and lysosomes were somewhat more numerous than after culture in $15 \mathrm{mM}$ L-leucine. There were also differences between the two experimental groups in the number and size of the B-cell mitochondria (see be- low). However, in both cases the mitochondrial matrix and cristae appeared normal. Neither figures of dividing or fusing mitochondria nor any megamitochondria were seen.

\section{Morphometry}

The stereological data are given in Table 1. It can be seen from its first part that there were no differences between the two experimental groups as regards the average islet cell volume $\left(\mathrm{V}_{\mathrm{vC}} / \mathrm{N}_{\mathrm{vC}}\right)$ or cell surface area $\left(\mathrm{S}_{\mathrm{VC}} / \mathrm{N}_{\mathrm{VC}}\right)$. As seen in the second part of the table, which gives the primary morphometric figures for the mitochondria, there was a smaller number of mitochondria per unit volume of tissue $\left(\mathrm{N}_{\mathrm{VM}}\right)$ in the islets cultured in $15 \mathrm{mM}$ L-leucine and their volume density of mitochondria $\left(\mathrm{V}_{\mathrm{VM}}\right)$ and mitochondrial outer surface area $\left(\mathrm{S}_{\mathrm{VM}}\right)$ were lower. On the other hand the average mitochondrial volume $\left(\mathrm{V}_{\mathrm{VM}} / \mathrm{N}_{\mathrm{VM}}\right)$, the average mitochondrial outer surface area $\left(\mathrm{S}_{\mathrm{VM}} / \mathrm{N}_{\mathrm{VM}}\right)$ 


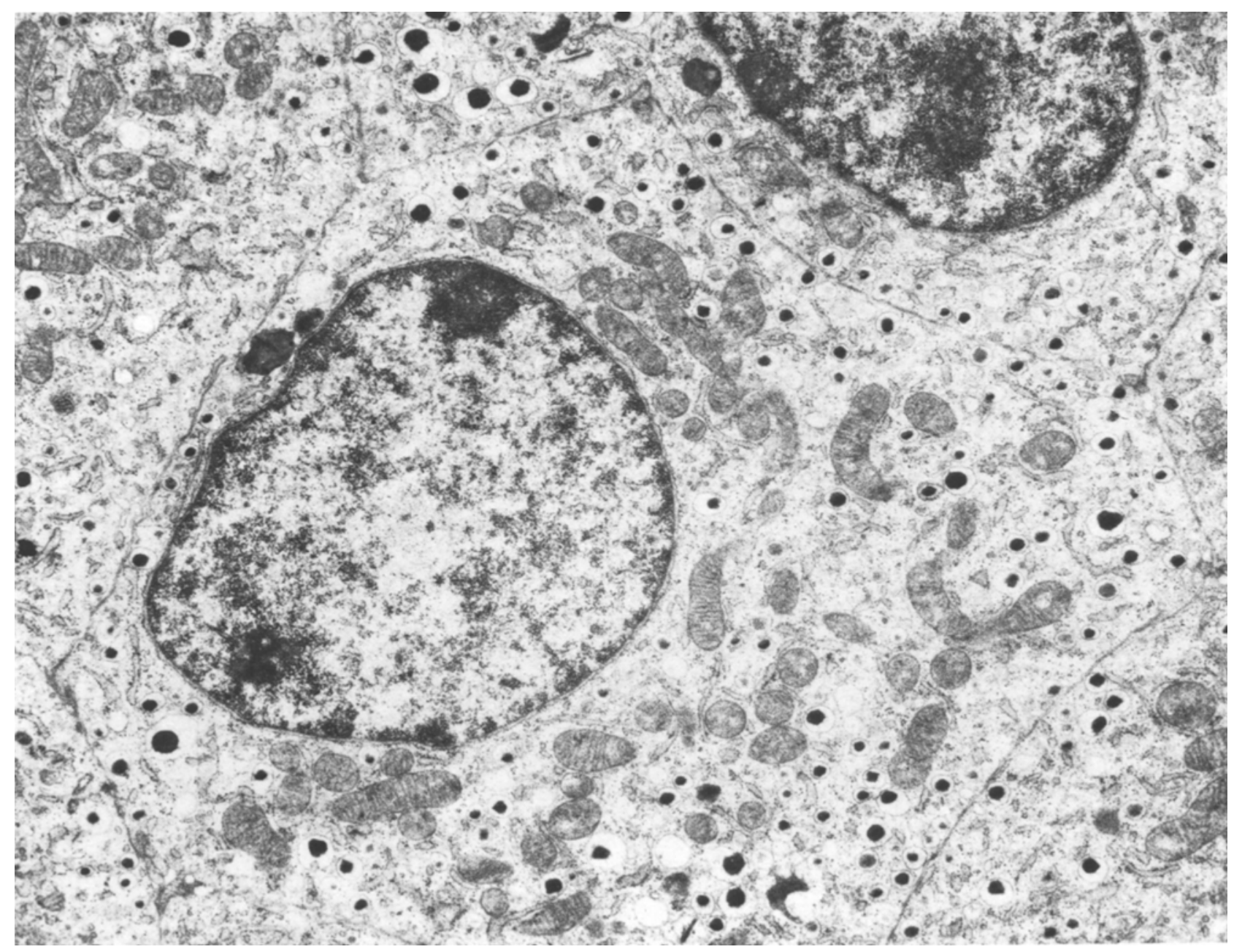

Fig. 2. Electron micrograph showing B-cells of a pancreatic islet cultured for one week in the control medium containing $3.3 \mathrm{mM}$ glucose and $0.5 \mathrm{mM}$ L-leucine. $\times 12300$

and the average cristae surface area $\left(\mathrm{S}_{\mathrm{VMC}} / \mathrm{N}_{\mathrm{VM}}\right)$ were increased after culture in $15 \mathrm{mM} \mathrm{L}$-leucine. None of the other calculated morphometric parameters differed between the two experimental groups, except for the average number of mitochondria per islet cell $\left(\mathrm{N}_{\mathrm{VM}} / \mathrm{N}_{\mathrm{VC}}\right)$ or per unit islet cell outer surface area $\left(\mathrm{N}_{\mathrm{VM}} / \mathrm{S}_{\mathrm{VC}}\right)$, which were both smaller after culture in 15 mM L-leucine.

\section{Insulin Release}

As shown in Figure 3 there was a higher content of insulin in the leucine supplemented culture medium, while the low-leucine cultured islets secreted only small amounts of insulin. At the end of the culture period we tested the insulin release capacity of the harvested islets in response to varying concentrations of glucose or leucine in the presence or absence of theophylline. Throughout all these studies it was observed that the basal insulin release (i.e. in the absence of glucose in the incubation medium) of the

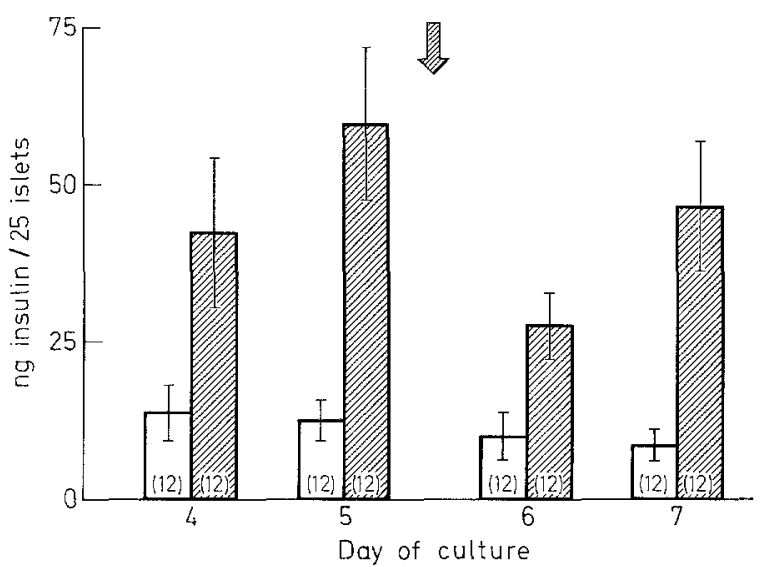

Fig. 3. Accumulation of immunoreactive insulin in the culture medium during culture in $3.3 \mathrm{mM}$ glucose $(\square)$ or $3.3 \mathrm{mM}$ glucose plus $15 \mathrm{mML}$-leucine (四). The medium was changed on the $3 \mathrm{rd}$ and 5 th days of culture (arrow). Each bar represents the mean \pm SEM of the observations made on 12 different culture dishes 

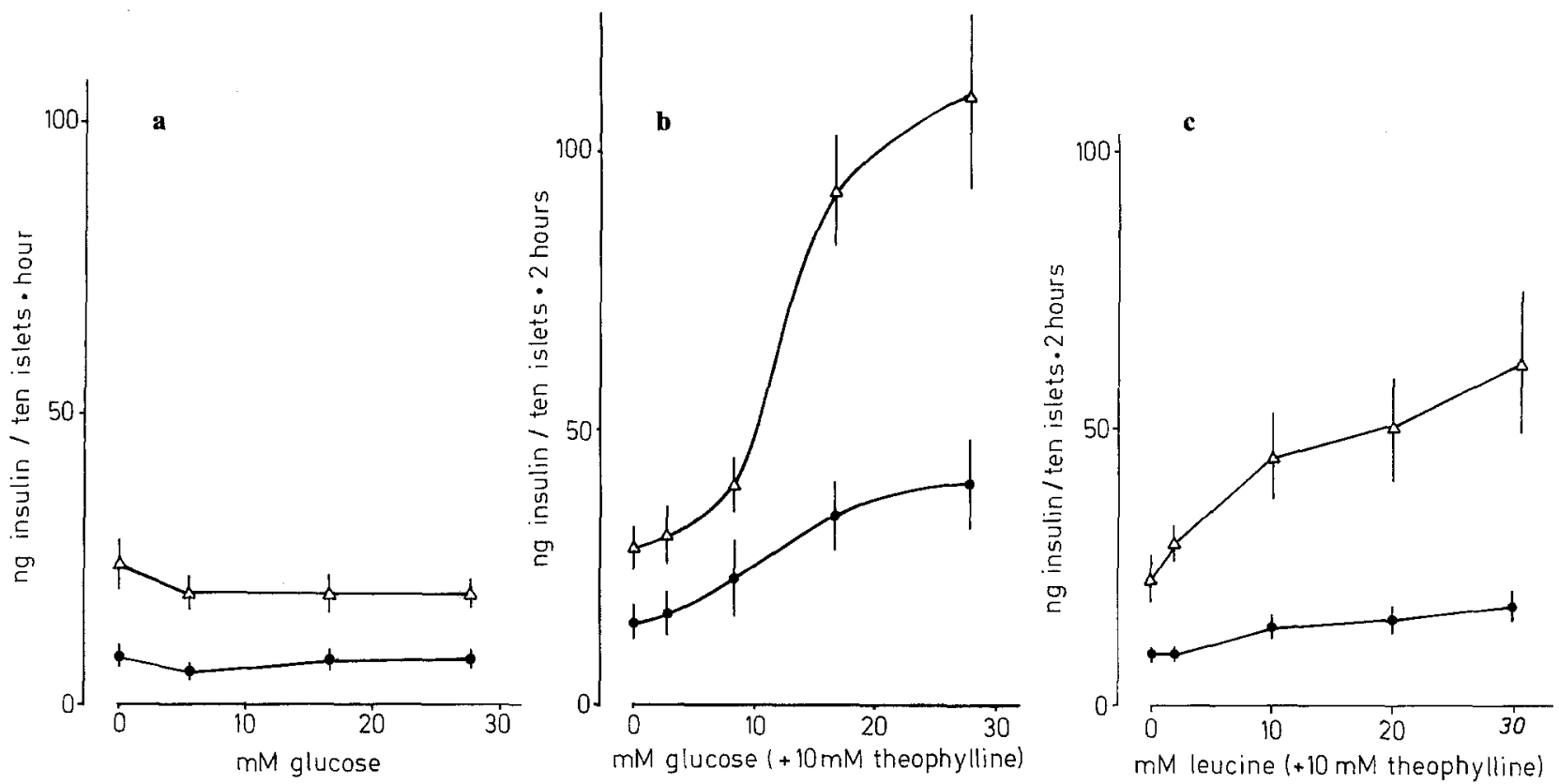

Fig. 4 a. Effects of different extracellular glucose concentrations on the insulin release of groups of ten islets cultured for one week in $3.3 \mathrm{mM}$ glucose $(\bullet-)$ ) or $3.3 \mathrm{mM}$ glucose plus $15 \mathrm{mM}$ L-leucine $(\triangle-\triangle)$. Each observation represents the mean \pm SEM of 6 experiments

Fig. $4 \mathrm{~b}$. Effects of different extracellular glucose concentrations and $10 \mathrm{mM}$ theophylline on the insulin release of groups of ten islets cultured for one week in $3.3 \mathrm{mM}$ glucose $(\bullet-)$ ) or $3.3 \mathrm{mM}$ glucose plus $15 \mathrm{mM}$ L-leucine $(\triangle \longrightarrow \Delta)$. Each observation represents the mean \pm SEM of 6 experiments

Fig. 4c. Effects of different extracellular L-leucine concentrations and $10 \mathrm{mM}$ theophylline on the insulin release of groups of ten islets cultured for one week in $3.3 \mathrm{mM}$ glucose $(\bullet-)$ or $3.3 \mathrm{mM}$ glucose plus $15 \mathrm{mM} \mathrm{L}$-leucine $(\Delta-\Delta)$. Each observation represents the mean \pm SEM of 8 experiments

leucine cultured islets was two to three times higher than that of the control islets. Figure $4 \mathrm{a}$ gives the dose-relationship between the extracellular glucose concentration and the insulin release of the cultured islets incubated in the absence of theophylline. It can be seen that the secretion of the leucine cultured islets was two to three times higher throughout all glucose concentrations, but neither this group of islets nor the control group was stimulated by glucose. In the presence of theophylline there was clearly a stimulation by glucose in that the insulin release of the leucine cultured islets was stimulated three to four times above the basal values at the higher concentrations of glucose (Fig. 4b). L-leucine itself stimulated insulin secretion of leucine cultured islets in a similar way to glucose (Fig. 4c).

The insulin contents of the cultured islets differed in that the islets cultured in $3.3 \mathrm{mM}$ glucose plus 0.5 $\mathrm{mM} \mathrm{L}$-leucine contained $155 \pm 20 \mathrm{ng}$ insulin/ 10 islets, while the islets cultured in the medium supplemented with $15 \mathrm{mM} \mathrm{L}$-leucine had an insulin content of $225 \pm$ $20 \mathrm{ng}$ insulin $/ 10$ islets $(\mathrm{p}<0.05 ; \mathrm{n}=5)$.

\section{Tritiated Water Production}

The rate of tritiated water production was determined at $2.8 \mathrm{mM}$ and $16.5 \mathrm{mM}$ glucose. It was found that in
$16.5 \mathrm{mM}$ glucose the leucine cultured islets produced significantly more tritiated water $(655 \pm 107$ pmoles $/ 10$ islets and $2 \mathrm{~h}((\mathrm{n}=6)))$ than the control islets $(393 \pm 64$ pmoles $/ 10$ islets and $2 \mathrm{~h}((\mathrm{n}=8)))(\mathrm{p}$ $<0.05)$. No major difference was observed between the two groups of islets in $2.8 \mathrm{mM}$ glucose, the values for the leucine cultured and control islets being $182 \pm$ $28(\mathrm{n}=6)$ and $123 \pm 19(\mathrm{n}=8)$ pmoles $/ 10$ islets and $2 \mathrm{~h}$ respectively $(\mathrm{p}<0.10)$.

\section{Oxidative Metabolism}

Figure 5 gives the rates of glucose oxidation at various extracellular glucose concentrations in the short-term experiments. It can be seen that the islets cultured in the presence of $15 \mathrm{mM} \mathrm{L}$-leucine displayed a higher oxidative rate at all concentrations of glucose. Furthermore the dose response curve of the leucine exposed islets was steepest between 5 and $11 \mathrm{mM}$ glucose, while the corresponding curve of the control group of islets was almost linear.

The rates of leucine oxidation of the two groups of islets were about the same in $1 \mathrm{mML}$-leucine ( $200 \pm$ 19 pmoles/20 islets and $2 \mathrm{~h}((\mathrm{n}=18))$ for the control islets and $184 \pm 25$ pmoles $/ 20$ islets and $2 \mathrm{~h}((\mathrm{n}=$ 21)) for the leucine cultured islets). In $15 \mathrm{mM}$ 


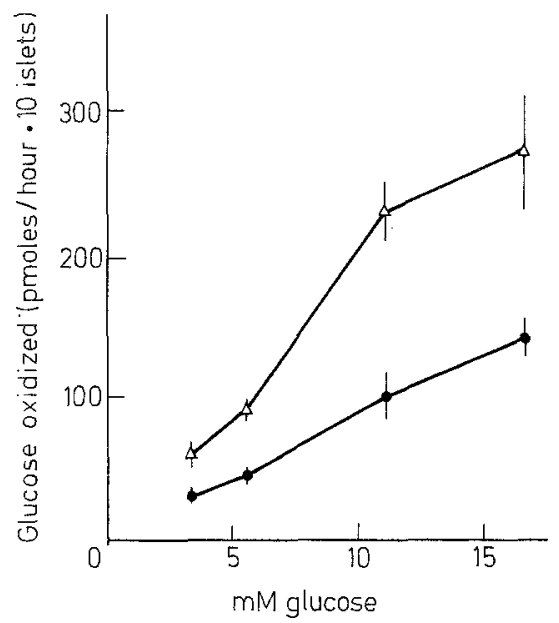

Fig. 5. The glucose oxidation rates of pancreatic islets cultured for one week in $3.3 \mathrm{mM}$ glucose $(\bullet-)$ ) or $3.3 \mathrm{mM}$ glucose plus $15 \mathrm{mM}$ L-leucine $(\Delta-\Delta)$. The glucose concentrations of the incubation medium during the oxidation experiments are given on the abscissa. Each point is the mean \pm SEM of $7-12$ batches of islets
L-leucine there was, however, a higher rate of $\mathrm{CO}_{2}$ production after culture in the medium supplemented with $15 \mathrm{mM} \mathrm{L}$-leucine, the values for the leucine cultured and control islets being $486 \pm 35(n=16)$ and $365 \pm 29(\mathrm{n}=17)$ pmoles $/ 20$ islets and $2 \mathrm{~h}$ respectively $(\mathrm{p}<0.01)$. It should be noted that no corrections were made for differences in the intracellular pools of leucine.

\section{Insulin Biosynthesis}

The first series of experiments, the results of which are given in Table 2, were performed with ${ }^{3} \mathrm{H}$-leucine as the radioactive precursor for insulin. No differences in the incorporation rate of tritiated leucine into the proinsulin-insulin pool were observed between the two groups of islets, while there was a markedly lower incorporation rate into the TCA-precipitable islet protein pool in the islets cultured in the presence of 15 mM L-leucine. Consequently, the percentage of the total radioactivity incorporated into the proinsulin-insulin fraction was considerably higher in the islets cultured in $15 \mathrm{mM} \mathrm{L-leucine.}$

These findings suggested great variations between the sizes of the intracellular pools of leucine in the two groups of islets. To further evaluate this ${ }^{3} \mathrm{H}$-phenyl- alanine was used as a radioactive precursor in a second series of experiments, the results of which are presented in Table 3. The incorporation studies were performed at low $(3.3 \mathrm{mM})$ and high $(16.7 \mathrm{mM})$ glucose concentrations for both groups of islets. As expected, the highest incorporation rates were observed for both groups of islets incubated in $16.7 \mathrm{mM}$ glucose. Furthermore, at both glucose concentrations the incorporation rates into the proinsulin-insulin pool of the control islets were only about $20 \%$ of those of the leucine cultured islets. In contrast, there were only minor differences in the incorporation rates into the TCA-precipitable islet protein pool, the ratio between the radioactivities incorporated into proinsulininsulin and into TCA-precipitable proteins being about five times higher for the islets cultured in $15 \mathrm{mM}$ L-leucine.

\section{DNA Synthesis}

Both groups of islets had similar incorporation rates of tritiated thymidine into islet DNA; $2.910 \pm 370$ $\mathrm{cpm} / \mu \mathrm{g}$ DNA $(\mathrm{n}=7)$ for the controls and 2.890 $\pm 330 \mathrm{cpm} / \mu \mathrm{g}$ DNA $(\mathrm{n}=8)$ for the leucine cultured islets.

\section{Discussion}

In order to study the long-term effects of widely varying extracellular glucose concentrations on the metabolism and insulin production of the pancreatic B-cells we have used a tissue culture system for isolated mouse pancreatic islets [6]. These studies have demonstrated that a marked functional hyperactivity of the B-cells as indicated by a high turn-over rate of insulin and an enhanced glucose metabolism is induced by exposure of the islets to an elevated $(28 \mathrm{mM})$ glucose concentration $[1,6,7]$. Conversely, a general depression of the B-cell activity was observed after culture of the islets in a subnormal $(3.3 \mathrm{mM})$ glucose concentration, indicated by a low rate of insulin biosynthesis and a glucose refractory insulin release [5]. These islets also displayed a mitochondrial hypertrophy [11], which, however, was accompanied by a slight depression of the glucose metabolism. The observations made on these low-glucose cultured islets were interpreted as suggesting that their impaired insulin release in response to glucose reflects a previous lack of glycaemic stimulus to the B-cell.

In the present investigation the primary aim was to see whether L-leucine might replace glucose as a longterm stimulus of the pancreatic B-cells in vitro. This particular amino acid was chosen since it has been found to stimulate insulin release both in vivo [17] and 
Table 2. Insulin biosynthesis as evidenced by the incorporation of ${ }^{3} \mathrm{H}$-leucine into proteins of islets cultured in $3.3 \mathrm{mM}$ glucose in the presence or absence of $15 \mathrm{mM} \mathrm{L}$-leucine. The two groups of cultured islets were harvested after culture for one week and then incubated for $2 \mathrm{~h}$ in the presence of $100 \mu \mathrm{Ci} / \mathrm{ml}^{3} \mathrm{H}$-leucine and $16.7 \mathrm{mM}$ glucose prior to the immunoadsorption. Each observation represents the mean $\pm S E M$ and the p-values are the statistical significances of the differences between the two groups of islets

\begin{tabular}{|c|c|c|c|c|}
\hline \multirow[b]{2}{*}{ Culture medium } & \multirow[b]{2}{*}{$\begin{array}{l}\text { Glucose } \\
\mathrm{mM}\end{array}$} & \multicolumn{3}{|c|}{$\begin{array}{l}\text { Radioactivity incorporated into proinsulin-insulin and islet trichloracetic acid precipitable } \\
\text { proteins }\left(\mathrm{cpm} \cdot 10^{-3} / 25 \text { islets } \cdot 2 \mathrm{~h}\right)\end{array}$} \\
\hline & & Proinsulin-insulin & $\begin{array}{l}\text { Trichloracetic } \\
\text { acid precipitable } \\
\text { proteins } \\
\text { II }\end{array}$ & $\begin{array}{l}\text { I in per } \\
\text { cent of II }\end{array}$ \\
\hline $3.3 \mathrm{mM}$ glucose & 16.7 & $2.68 \pm 0.53(10)$ & $59.8 \pm 7.2(10)$ & $4.7 \pm 1.0(10)$ \\
\hline $\begin{array}{l}3.3 \mathrm{mM} \text { glucose } \\
+15 \mathrm{mM} \text { L-leucine }\end{array}$ & 16.7 & $\begin{array}{l}2.05 \pm 0.23(11) \\
\text { (n.s.) }\end{array}$ & $\begin{array}{l}13.7 \pm 1.0(11) \\
(\mathrm{p}<0.001)\end{array}$ & $\begin{array}{l}14.7 \pm 1.0(11) \\
(\mathrm{p}<0.001)\end{array}$ \\
\hline
\end{tabular}

Table 3. Effects of glucose on the incorporation of ${ }^{3} \mathrm{H}$-phenylalanine into the proteins of islets cultured in $3.3 \mathrm{mM}$ glucose or $3.3 \mathrm{mM}$ glucose plus $15 \mathrm{mM}$ L-leucine. The two groups of islets were harvested after culture for one week and then incubated for $2 \mathrm{~h}$ in the presence of 200 $\mu \mathrm{Ci} / \mathrm{ml}{ }^{3} \mathrm{H}$-phenylalanine and 3.3 or $16.7 \mathrm{mM}$ glucose. The means $\pm S E M$ are shown together with the number of individual determinations (within parentheses) and the statistical significance of differences between the two groups of cultured islets

\begin{tabular}{|c|c|c|c|c|}
\hline \multirow[b]{2}{*}{ Culture medium } & \multirow[b]{2}{*}{$\begin{array}{l}\text { Glucose } \\
\mathrm{mM}\end{array}$} & \multicolumn{3}{|c|}{$\begin{array}{l}\text { Radioactivity incorporated into proinsulin-insulin and islet trichloracetic acid precipitable } \\
\text { proteins }\left(\mathrm{cpm} \cdot 10^{-3} / 25 \text { islets } \cdot 2 \mathrm{~h}\right)\end{array}$} \\
\hline & & Proinsulin-insulin & $\begin{array}{l}\text { Trichloracetic } \\
\text { acid precipitable } \\
\text { proteins } \\
\text { II }\end{array}$ & $\begin{array}{l}\text { I in per } \\
\text { cent of II }\end{array}$ \\
\hline $3.3 \mathrm{mM}$ glucose & 3.3 & $5.42 \pm 1.78(6)$ & $184 \pm 37(6)$ & $2.7 \pm 0.4(6)$ \\
\hline $\begin{array}{l}3.3 \mathrm{mM} \text { glucose } \\
+15 \mathrm{mM} \text { L-leucine }\end{array}$ & 3.3 & $\begin{array}{l}25.53 \pm 6.00(7) \\
(p<0.01)\end{array}$ & $\begin{array}{l}165 \pm 28(7) \\
\text { (n.s.) }\end{array}$ & $\begin{array}{l}14.5 \pm 1.4(7) \\
(p<0.001)\end{array}$ \\
\hline $3.3 \mathrm{mM}$ glucose & 16.7 & $8.54 \pm 1.23(9)$ & $231 \pm 28(9)$ & $3.7 \pm 0.3(9)$ \\
\hline $\begin{array}{l}3.3 \mathrm{mM} \text { glucose } \\
+15 \mathrm{mM} \text { L-leucine }\end{array}$ & 16.7 & $\begin{array}{l}55.67 \pm 5.77(10) \\
(p<0.001)\end{array}$ & $\begin{array}{l}313 \pm 26(10) \\
(p<0.05)\end{array}$ & $\begin{array}{l}17.6 \pm 0.9(10) \\
(p<0.001)\end{array}$ \\
\hline
\end{tabular}

in vitro $[29,33]$. Furthermore, L-leucine stimulates insulin biosynthesis [3], probably by being metabolized by the pancreatic B-cells $[22,23]$. It should be pointed out in this context that all these effects exerted by L-leucine on the islets have been demonstrated in short-term experiments in the absence of glucose, while in the present culture experiments $3.3 \mathrm{mM}$ glucose and calf serum were added to the medium in order to ensure a good general viability of the explanted islet specimens.

Observations on the morphological and functional characteristics of the cultured islets can be made at two different stages of the present experimental procedure; either during maintenance in the culture dishes or in short-term experiments at the end of the culture period. As regards the culture period, there was a higher rate of insulin accumulation in the leucine-supplemented culture medium and in general these islets migrated along and stuck to the bottom of the dishes in the same way as do islets exposed to a high glucose concentration. This migration of the islet cells was not due to cell regeneration, since the rate of thymidine incorporation was not different from that of the control islets.

At the end of the culture period the electron microscopic differences between the two groups of cultured islets resembled the marked divergence in ultrastructure between mouse islets cultured in high ( 28 $\mathrm{mM})$ and low $(3.3 \mathrm{mM})$ extracellular glucose concentrations $[7,11]$. The former, like the B-cells of islets cultured in $15 \mathrm{mM}$ L-leucine, displayed a well developed secretory apparatus. The granulated endoplasmic reticulum of the leucine cultured islets, however, consisted mainly of cisternae instead of stacked lamellae, which were particularly prominent in the islets cultured at a high glucose concentration. Furthermore, the number of secretory granules in the B-cells of the L-leucine cultured islets was greater and not reduced to the same extent as after culture in a high glucose concentration $[7,11]$. 
The detailed stereological examination of the ultrastructure of the cultured islet cells showed that neither the average cell volume nor the average cell surface area differed between the cells exposed to the two different leucine concentrations, which suggests that in the present situation the cell size as such is not influenced by the functional and metabolic rate of the islet cells. In the morphometry of the islet cell mitochondria, marked changes were, however, induced by a high leucine concentration in the culture medium; calculations of the mean mitochondrial volume, outer surface area and cristae surface area consistently showed that the mean size of each individual mitochondrion was bigger after culture in $15 \mathrm{mM}$ L-leucine. There are, however, no reasons to believe that this enlargement of the individual mitochondria was due to mere swelling, since there was neither a dilution of the matrix substance nor a decrease in the density of the cristae surface area per unit mitochondrial volume.

The discrepancy observed between the effects of a high glucose and a high L-leucine concentration on the islet cell mitochondria is quite obvious and further demonstrates the great value of using morphometric techniques for evaluating quantitatively the ultrastructure of islet cells under different experimental conditions [11, 14]. In our previous study it was suggested that the mitochondrial hypertrophy of the islet cells subjected to the subnormal glucose concentration was due to adaptive changes towards oxidation of energy yielding substrates other than glucose. The present results seem to fit in well with such an interpretation, since there was again a marked increase of the surface area of mitochondrial cristae per unit test volume after leucine exposure compared with the same figures for high glucose-cultured islets [11]. Further support for such an interpretation was recently obtained in B-cells of the normal islets of hypoglycaemic rats suffering from an X-ray induced insulinoma, which displayed very prominent and hypertrophic mitochondria besides ultrastructural signs of a marked general cellular hypoactivity [30].

The long-term effects of leucine-supplementation of the culture medium on the specific functions of the islets were assessed in measurements of the insulin release and biosynthesis of the cultured islets. There was a higher B-cell activity, as indicated by the increased basal insulin release, which could be markedly stimulated by addition to the incubation medium of glucose or leucine together with theophylline. It was, however, not stimulated by addition of glucose alone. A similar glucose refractoryness of the insulin release in combination with a high basal secretion irrespective of whether theophylline was added or not, has been observed after a prolonged glucose stimulation of iso- lated islets in culture [1]. This discrepancy between islets cultured in the presence of a high concentration of L-leucine or glucose in their insulin secretory capacity in the presence of theophylline might be explained by the considerably lower insulin content of the high-glucose cultured islets [7], which means that not less than 50 per cent of their total insulin store is mobilized during a 60 minutes' incubation period [1]. Alternatively the adenylate cyclase system of the B-cells may be affected differently by the addition of leucine or glucose to the culture medium. Indeed, the glucose concentration of the culture medium has been found to influence the activities of adenylate cyclase and phosphodiesterase in cultured islets $[10,26]$.

The effects of $\mathrm{L}$-leucine on the insulin biosynthesis of islets in culture were very obvious and could be demonstrated irrespective of whether tritiated leucine or phenylalanine was used as the radioactive precursor of insulin. A preferential incorporation into the proinsulin-insulin pool, indicated by the percentage figures, was observed with both glucose concentrations ( 3.3 and $16.7 \mathrm{mM}$ ) used in the incorporation studies, indicating that a high biosynthetic rate was maintained also at the low glucose concentration. The incorporation of tritiated phenylalanine into the proinsulin-insulin pool in absolute terms was, however, twice as high at $16.7 \mathrm{mM}$ glucose, indicating that the insulin biosynthetic process was still sensitive to the extracellular glucose concentration. The results of the synthesis experiments also suggest that the rate of insulin biosynthesis was sufficient to compensate for the continuously high secretion of insulin during the culture, since the insulin content of the leucine cultured islets was even higher than that of the control islets.

A slight and general reduction in the islet glucose metabolism has been described both in islets isolated from starved animals [20] and islets cultured in a substimulatory glucose concentration [5]. It was thus of interest to characterize the energy metabolism of the leucine cultured islets in order to explain their high functional activity. The three metabolic variables measured in the present study all displayed higher rates for leucine cultured islets in comparison to those of the controls. As regards the rates of glucose oxidation at different extracellular glucose concentrations they were all very similar to those of islets cultured in 6 $\mathrm{mM}$ glucose $[1,5]$, suggesting an indirect effect of leucine on the glycolytic pathway, although the prerequisites for gluconeogenesis in the islets are, however, poor [12].

In conclusion we have found that L-leucine may partially replace glucose in the functional stimulation of pancreatic B-cells maintained in tissue culture. Thus the general depression of B-cell activity, which 
follows a decrease of the glucose concentration in the culture medium, was prevented, as indicated by the higher rates of energy metabolism and insulin biosynthesis of the L-leucine exposed islets and the concomitant ultrastructural signs of a high functional activity. There was, however, no general or total substituting effect of L-leucine for all known stimulatory effects of glucose in cultured islets in that there was no enhancement of the DNA-synthesis normally observed after culture in $16.7 \mathrm{mM}$ glucose [2]. Furthermore glucose and L-leucine seem to exert divergent effects on the system of mitochondrial cristae, thus indicating that some important regulatory mechanisms for the biosynthesis and release of insulin may be located in the mitochondria. The question whether L-leucine may replace glucose in the culture medium in order to maintain a normal glucose receptor mechanism remains to be answered. It must be kept in mind that this mechanism is highly dependent on the glucose concentration of the culture medium. Thus, islets cultured in $6 \mathrm{mM}$ glucose maintain an adequate insulin release response to glucose stimulation [5], while islets cultured in $28 \mathrm{mM}$ glucose are glucose refractory [1]. Similarly, it cannot be excluded that leucine concentrations lower than that used in the present study might have mimicked the effects of 6 $\mathrm{mM}$ glucose in the culture medium as regards glucose regulated insulin secretion.

It is possible that the ability of L-leucine to serve as a substitute for glucose may be due to its metabolic degradation in the B-cells. This concept is supported by the fact that insulin biosynthesis of islets in culture is stimulated by islet cell substrates other than L-leucine and glucose [4]. Further, insulin biosynthesis in non-cultured islets is closely correlated with the ability of some amino acids to serve as fuels for the B-cells and/or to influence islet cell metabolism [3]. In support of the latter we have recently observed that the synthetic, non-metabolizable leucine analogue 2-amino-norbornane-2 carboxylic acid (BCH), which is known to stimulate both insulin release [13] and biosynthesis [3], increases very markedly the oxygen uptake of isolated pancreatic islets (Hellerström \& Andersson, to be published). The results of the present study also suggest that special attention should be drawn to the amino-acid composition of the culture medium in order to find the ideal medium for islet storage.

Acknowledgements. This work was supported by the Swedish Medical Research Council, the Swedish Diabetes Association, the Helge Ax:son Johnson Foundation and the Nordic Insulin Fund. We thank Mrs. M. Engkvist, Miss A. Nordin, Miss K. Orrsten and Mrs. K. Brunstedt for their excellent technical assistance.

\section{References}

1. Andersson, A.: Long-term effects of glucose on insulin release and glucose oxidation by mouse pancreatic islets maintained in tissue culture. Biochem. J. 140, 377-382 (1974)

2. Andersson, A.: Synthesis of DNA in isolated pancreatic islets maintained in tissue culture. Endocrinology 96, 1051-1054 (1975)

3. Andersson, A.: Stimulation of insulin biosynthesis in isolated mouse islets by L-leucine, 2-aminonorbornane-2-carboxylic acid and $\alpha$-ketoisocaproic acid. Biochim. biophys. Acta. (Amst.) 437, 345-353 (1976)

4. Andersson, A.: Effects of exogenous substrates and insulin secretagogues on insulin biosynthesis of cultured pancreatic islets. Diabetologia 12, 376 (1976)

5. Andersson, A., Gunnarsson, R., Hellerström, C.: Long-term effects of a low extracellular glucose concentration on glucose metabolism and insulin biosynthesis and release of mouse pancreatic islets maintained in tissue culture. Acta endocr. (Kbh.) 82, 318-329 (1976)

6. Andersson, A., Hellerström, C.: Metabolic characteristics of isolated pancreatic islets in tissue culture. Diabetes 21, (Suppl. 2), 546-554 (1972)

7. Andersson, A., Westman, J., Hellerström, C.: Effects of glucose on the ultrastructure and insulin biosynthesis of isolated mouse pancreatic islets maintained in tissue culture. Diabetologia 10, 743-753 (1974)

8. Ashcroft, S. J. H., Weerasinghe, L. C. C., Bassett, J. M., Randle, P. J.: The pentose cycle and insulin release in mouse pancreatic islets. Biochem. J. 126, 525-532 (1972)

9. Berne, C.: Anti-insulin serum coupled to Sepharose 4B as a tool for the investigation of insulin biosynthesis in the B-cells of obese hyperglycemic mice. Endocrinology 97, 1241-1247 (1975)

10. Berne, C., Andersson, A.: Long-term effects of a high glucose concentration on cyclic nucleotide phosphodiesterase activity in mouse pancreatic islets maintained in tissue culture. Biochem. J. 156, 461-463 (1976)

11. Borg, L. A. H., Andersson, A., Berne, C., Westman, J.: Glucose dependent alterations of mitochondrial ultrastructure and enzyme content in mouse pancreatic islets maintained in tissue culture. A morphometrical and biochemical study. Cell Tiss. Res. 162, 313-321 (1975)

12. Brolin, S. E., Berne, C., Petersson, B., Larsson, A.: Histochemical staining and microchemical studies of fructose-1,6diphosphate splitting enzymes in the pancreatic islets and liver of NZO mice. J. Histochem. Cytochem 16, 654-658 (1968)

13. Christensen, H. N., Hellman, B., Lernmark, A., Sehlin, J., Tager, H. S., Täljedal, I.-B.: In vitro stimulation of insulin release by non-metabolizable, transport-specific amino acids. Biochim. biophys. Acta (Amst.) 241, 341-348 (1971)

14. Dean, P. M.: Ultrastructural morphometry of the pancreatic B-cell. Diabetologia 9, 115-119 (1973)

15. DeHoff, R. T., Rhines, F. N.: Determination of number of particles per unit volume from measurements made on random plane sections: the general cylinder and the ellipsoid. Trans. Met. Soc. AIME. 221, 975-982 (1961)

16. Eagle, H.: Amino acid metabolism in mammalian cell cultures. Science 130, 432-437 (1959)

17. Fajans, S. S., Floyd, Jr., J. C., Knopf, R. F., Conn, J. W.: Effect of amino acids and proteins on insulin secretion in man. Recent Progr. Hormone Res. 23, 617-656 (1967)

18. Gey, G. O., Gey, M. K.: The maintenance of human normal cells and tumor cells in continuous culture. I. Preliminary report: cultivation of mesoblastic tumors and normal tissue and notes on methods of cultivation. Amer. J. Cancer 27, 45-76 (1936) 
19. Glagoleff, A.: On the geometrical methods of quantitative mineralogical analysis of rocks. Trans. Inst. Econom. Mineral. 59, 1-47 (1933)

20. Hedeskov, C. J., Capito, K.: The effect of starvation on insulin secretion and glucose metabolism in mouse pancreatic islets. Biochem. J. 140, 423-433 (1974)

21. Heding, L.: Determination of total serum insulin (IRI) in insulin-treated diabetic patients. Diabetologia 8, 260-266 (1972)

22. Hellerström, C., Westman, S., Marsden, N., Turner, D.: Oxygen consumption of the B-cells in relation to insulin release. In: The structure and metabolism of the pancreatic islets (eds. S. Falkmer, B. Hellman, I.-B. Täljedal), pp. 315-328. Oxford: Pergamon Press Ltd 1970

23. Hellman, B., Sehlin, J., Täljedal, I.-B.: Effects of glucose and other modifiers of insulin release on the oxidative metabolism of amino acids in micro-dissected pancreatic islets. Biochem. J. 123, 513-521 (1971)

24. Hennig, A.: Bestimmung der Oberfläche beliebig geformter Körper mit besonderer Anwendung auf Körperhaufen im mikroskopischen Bereich. Mikroskopie 11, 1-20 (1956)

25. Hilliard, J. E.: The calculation of the mean caliper diameter of a body for use in the analysis of the number of particles per unit volume. In: Stereology (ed. H. Elias), pp. 211-215. BerlinHeidelberg-New York: Springer 1967

26. Howell, S. L., Green, J. C., Montague, W.: A possible role of adenylate cyclase in the long-term dietary regulation of insulin secretion from rat islets of Langerhans. Biochem. J. 136, 343-349 (1973)

27. Howell, S. L., Taylor, K. W.: Potassium ions and the secretion of insulin by islets of Langerhans incubated in vitro. Biochem. J. 108, 17-24 (1968)

28. Krebs, H. A., Henseleit, K.: Untersuchungen über die Harnstoffbildung im Tierkörper. Hoppe-Seylers Z. physiol. Chem. 210, 33-66 (1932)

29. Lernmark, $\AA$.: Specificity of leucine stimulation of insulin release. Hormones 3, 14-21 (1972)
30. Like, A. A.: Morphology of B-cells in vitro. In: Proceedings, 5th Workshop Conference Hoechst on Pancreatic Beta Cell Culture, Kitzbühel 5-9 October 1976. Amsterdam: Excerpta Medica (in press)

31. Luft, J. H.: Improvements in epoxy resin embedding methods. J. biophys. biochem. Cytol. 9, 409-414 (1961)

32. Malaisse, W. J., Malaisse-Lagae, F.: Stimulation of insulin secretion by noncarbohydrate metabolites. J. Lab. clin. Med. 72, 438-448 (1968)

33. Milner, R. D. G., Hales, C. N.: The role of calcium and magnesium in insulin secretion from rabbit pancreas studied in vitro. Diabetologia 3, 47-49 (1967)

34. Reynolds, E. S.: The use of lead citrate at high $\mathrm{pH}$ as an electron-opaque stain in electron microscopy. J. Cell Biol. 17, 208-212 (1963)

35. Tomkeieff, S. I.: Linear intercepts, areas and volumes. Nature (Lond.) 155, 24 (1945)

36. Watson, M. L.: Staining of tissue sections for electron microscopy with heavy metals. J. biophys: biochem. Cytol. 4, 475-478 (1958)

37. Weibel, E. R.: Principles and methods for the morphometric study of the lung and other organs. Lab. Invest. 12, 131-155 (1963)

Received: July 12, 1976, and in revised form: October 25, 1976 